
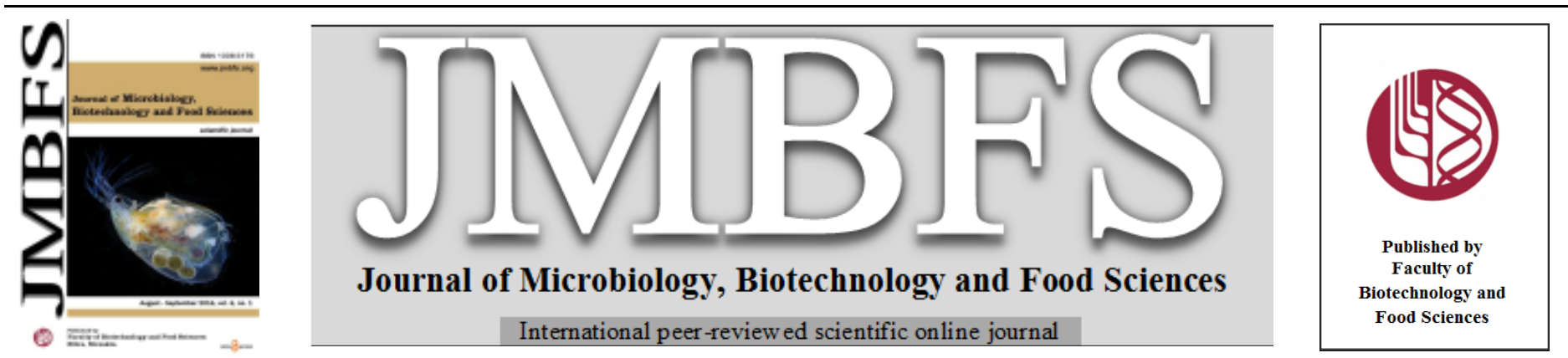

\title{
ANTI-OXIDATIVE POTENTIAL OF HONEY AND ASCORBIC ACID IN YOGHURT FORTIFIED WITH OMEGA-3 FATTY ACIDS
}

\author{
Murage M.Wanjiku ${ }^{* 1}$, Mbatia B.Nyambura ${ }^{2}$, Muge E.Kirwa ${ }^{3}$, Mwaniki Mercy. $W^{4}$ \\ Address(es): \\ ${ }^{1}$ University of Kabianga, Department of Biological Sciences, P.O Box 2030-20200 Kericho, Kenya. \\ ${ }^{2}$ United States International University-Africa (USIU-A), School of Pharmacy and Health Sciences P.O Box 14634-00800, Nairobi Kenya. \\ ${ }^{3}$ University of Nairobi, Department of Biochemistry, P.O Box 30197 Nairobi, Kenya. \\ ${ }^{4}$ Technical University of Kenya, Department of Food Science and Technology, P.O Box 52428-00200, Nairobi, Kenya.
}

*Corresponding author: shiksmurage@gmail.com

doi: 10.15414/jmbfs.2016.6.1.702-706

\section{ARTICLE INFO}

Received 17. 2. 2016

Revised 24. 3. 2016

Accepted 11. 4. 2016

Published 1. 8. 2016

Regular article

open ${ }_{\text {ACCESS }}$

\begin{abstract}
Processing of Nile perch (Lates niloticus), a commercial fish in Eastern Africa; results in omega-3 polyunsaturated fatty acids (PUFA) rich by-products. Oil derived from such by-products can be incorporated in commonly consumed foods; however, these fatty acids are highly susceptible to oxidation. Honey and ascorbic acid are natural anti-oxidants that could play a role in preventing lipid oxidation. In the current study, omega-3 rich oil was extracted from L. niloticus viscera and added to yoghurt samples. The aim of the study was to investigate the biochemical and anti-oxidative parameters in honey and lemon juice and use them as antioxidants in the fortified yoghurt samples. Stability of the fortified yoghurt was monitored over one month storage period. Ascorbic acid Equivalent Antioxidant Capacity (AEAC) of lemon juice and honey were $312 \pm 2.34$ and $197 \pm 3.65 \mathrm{mg} / \mathrm{L}$, respectively. The DPPH radical scavenging activity showed that honey $(86.16 \pm 1.43 \%)$ tended to be highly active in the reaction with DPPH compared to lemon juice $(71.29 \pm 3.52 \%)$. After four weeks of storage, the peroxide value (PV), anisidine value (AV) and (free fatty acid) (FFA) contents were within the acceptable range with the honey fortified sample being most stable. The ascorbic acid content was highest in lemon juice fortified samples $(30 \mathrm{mg} / 100 \mathrm{~g})$ while in honey fortified samples were below $1 \mathrm{mg} / 100 \mathrm{~g}$. The $\mathrm{pH}$ in all the samples decreased slightly over time. Honey and lemon juice are therefore good natural anti-oxidants and their anti-oxidative potential can be utilized in the prevention of lipid oxidation in omega-3 fortified yoghurts.
\end{abstract}

Keywords: Omega-3 fatty acids, honey, ascorbic acid, yoghurt, antioxidants

\section{INTRODUCTION}

Omega-3 fatty acids are examples of bioactive substances whose interest has increased over the years in scientific research due to their proven health benefits. The human body is not able to synthesize these fatty acids and hence must be provided through diet (Amegovu et al., 2014) or supplementation. For this reason, fortification of foods with omega-3 PUFAs has therefore been proposed as a practical approach towards increasing the consumption of these fatty acids (Metcalf et al., 2003). However, the incorporation of these fatty acids in foods, the processing and handling is associated with nutritional challenges for their healthy delivery (Huber et al., 2009). The extreme sensitivity of fish oils to oxidation can easily lead to the development of off-flavors and cause significant loss of product quality, stability, nutritional value, bio-availability and the overall acceptability of the food product (Jellinek, 1971; Pak, 2005). The high rate of fish oil oxidation can be reduced by incorporation of synthetic or natural antioxidants (Huber et al., 2009). The use of natural antioxidants is more preferred due to many health risks such as cancer associated with synthetic antioxidants (Stip \& Bels, 2009). Honey and vitamin C derived from citrus fruits are natural antioxidants that could be used to delay or inhibit oxidation of Omega-3 PUFAs. Natural honey is associated with several biological properties ranging from anti-oxidant, anti-inflammatory, anti-bacterial, anti-viral, anti-biotic and wound healing to immune-stimulatory properties (Seema \& Simon, 2013) Anti-oxidative potential of honey is attributed to the presence of high concentrations of important phenolic, flavonoid and carotenoids (AlvarezSuarez et al., 2010). The amount and type of these antioxidant compounds depends largely on the floral source/variety of honey, climatic conditions and processing (Mohammed et al., 2010). Vitamin C is a natural antioxidant whose consumption is required for the prevention of scurvy and maintenance of healthy skin, gums and blood vessels. As an antioxidant, it has been reported to reduce the risk of arteriosclerosis, cardiovascular diseases and some forms of cancer (Sarkar et al., 2009). The aim of this study was to evaluate the potential of honey and ascorbic acid in inhibiting lipid oxidation in omega- 3 fortified yoghurt. The effectiveness of the antioxidants in the preservation of the fortified yoghurt product over one month period was also evaluated.

\section{MATERIALS AND METHODS}

\section{Materials}

Nile perch viscera were purchased from a local Nile perch processing plant in Nairobi (W.E. Tiley ltd, Nairobi, Kenya). Fresh milk, skimmed milk, sugar, citrus fruits (lemon, tangerine and orange) and three honey samples (green forest, Amboseli and Baringo) were obtained from a local store (Tusky's Supermarket Ltd). Starter cultures of Lactobacillus bulgaricus and Streptococcus thermophilus were purchased locally (Pradip enterprises ltd). All the solvents and chemicals used were of analytical grade.

\section{Analysis of Honey}

\section{Proline content}

The method described by the International Honey Commission (IHC, 1999) was used to determine the proline content. An aliquot $(0.5 \mathrm{~mL} \approx 0.05 \mathrm{mg})$ of honey solution was transferred to a test tube. For blank test, $0.5 \mathrm{~mL}$ was transferred to a second tube and $0.5 \mathrm{~mL}$ of $(0.032 \mathrm{mg} / \mathrm{mL})$ proline standard solution was dispensed into three other tubes. To each tube, $1 \mathrm{~mL}$ of formic acid and $1 \mathrm{~mL}$ of ninhydrin (Fisher Scientific, United Kingdom) solution was added. The tubes were capped carefully and shaken vigorously for $15 \mathrm{~min}$. The tubes were then placed in a boiling water bath for $15 \mathrm{~min}$ and there after transferred to another water bath and incubated at $70^{\circ} \mathrm{C}$ for $10 \mathrm{~min}$. 2-propanol water solution $(5 \mathrm{~mL})$ was added to each tube followed by immediate capping. The tubes were left to 
cool for approximately $45 \mathrm{~min}$ and the absorbance values measured at $510 \mathrm{~nm}$. Proline concentration in $\mathrm{mg} / \mathrm{kg}$ of honey was calculated as follows:

\section{Proline $(\mathrm{mg} / \mathrm{kg})=(\mathbf{E s} / \mathbf{E a}) \times\left(\mathbf{E}_{1} / \mathbf{E}_{2}\right) \times 80$,}

Where: Es is the absorbance of the sample solution; Ea is the absorbance of the proline standard solution (average of three readings); $\mathbf{E}_{\mathbf{1}}$ is the $\mathrm{mg}$ of proline used for standard solution; $\mathbf{E}_{2}$ is the weight of honey in grams; $\mathbf{8 0}$ is the dilution factor. The mean of three readings was used.

\section{Total phenolic content}

This was determined by a method described by Singleton et al., (1999). Each honey sample $(5 \mathrm{~g})$ was diluted to $50 \mathrm{~mL}$ using distilled water. A $1 \mathrm{~mL}$ of this solution was mixed with $2.5 \mathrm{~mL}$ of $0.2 \mathrm{~N}$ Folin-Ciocalteu reagents (SigmaAldrich Chemie, Steinheim, Germany) for $5 \mathrm{~min}$ after which, $2 \mathrm{~mL}$ of $75 \mathrm{~g} / \mathrm{l}$ sodium carbonate $\left(\mathrm{Na}_{2} \mathrm{CO}_{3}\right)$ was added. The reaction mixture was incubated for $2 \mathrm{~h}$ at room temperature and the absorbance read at $760 \mathrm{~nm}$ against a methanol blank. Gallic acid $(0-200 \mathrm{mg} / \mathrm{l})$ was used as a standard to make a calibration curve. The mean of three readings was used and the total phenolic content expressed in mg of gallic acid equivalents (GAE)/100g of honey.

\section{Carotenoids content}

This was done according to the method described by Ferreira et al (2007). A sample of honey $(100 \mathrm{mg})$ was vigorously shaken with $10 \mathrm{mLof}$ acetone-hexane mixture (4:6) for $1 \mathrm{~min}$ and filtered through Whatman No. 4 filter paper (Sigam Aldrich, USA). The absorbance of the filtrate was then measured at 453, 505 and $663 \mathrm{~nm}$. Contents of $\beta$-carotene and lycopene were calculated according to the following equations:

Lycopene $(\mathrm{mg} / 100 \mathrm{~mL})=\mathbf{- 0 . 0 4 5 8} \mathrm{A}_{663}+0.372 \mathrm{~A}_{505}-0.0806 \mathrm{~A}_{453} ;$

$\beta$-carotene $(\mathrm{mg} / 100 \mathrm{~mL})=0.216 A_{663}-0.304 A_{505}+0.452 A_{453}$.

The results were expressed as $\mathrm{mg}$ of carotenoid $/ \mathrm{kg}$ of honey

\section{Color intensity $\left(\mathbf{A B S}_{450}\right)$}

The mean absorbance of honey samples was determined according to the method described by Beretta et al. (2005). Briefly, honey samples were diluted to $50 \%$ $(\mathrm{w} / \mathrm{v})$ with warm $\left(45-50^{\circ} \mathrm{C}\right)$ distilled water, and the resulting solution filtered to remove large particles. The absorbance was measured at 450 and $720 \mathrm{~nm}$ and the difference in absorbance was expressed as milli absorbance units (mAU).

$$
\text { mAU of honey }=\left(\mathrm{ABS}_{700}-\mathrm{ABS}_{450}\right)
$$

\section{Determination of anti-oxidative properties of honey}

\section{DPPH radical scavenging activity}

The method described by Ferreira et al.(2007) was used to determine the DPPH radical scavenging activity of the honey samples. The honey samples $(12.5 \mu \mathrm{L}$ $100 \mu \mathrm{L} / \mathrm{mL}$ ) were prepared in methanol. An aliquot $(2 \mathrm{~mL})$ of DPPH (Sigma Aldrich, USA) solution ( $0.002 \%$ in methanol) was added to $2 \mathrm{~mL}$ of the prepared samples. The samples were incubated at room temperature in the dark for 30 minutes and the optical density read at $517 \mathrm{~nm}$. The absorbance of the DPPH control was also noted. The scavenging activity of the samples was calculated using the formula:

Scavenging activity $(\%)=[(\mathbf{A}-\mathbf{B}) / \mathbf{A}] \times 100$.

Where: $\mathbf{A}$ is absorbance of DPPH and $\mathbf{B}$ is absorbance of DPPH and honey sample.

\section{Ferric reducing power}

This was done according to the method described by Ferreira et al. (2007) Various concentrations of water honey solutions $(2.5 \mathrm{~mL})$ were mixed with 2.5 $\mathrm{mL}$ of $200 \mathrm{mmol} / \mathrm{L}$ sodium phosphate buffer $\mathrm{pH} 6.6$ and $2.5 \mathrm{~mL}$ of $1 \%$ potassium ferricyanide. The mixture was then incubated at $50^{\circ} \mathrm{C}$ for $20 \mathrm{~min}$. To the mixture, $2.5 \mathrm{~mL}$ of $10 \%$ trichloro acetic acid (w/v) (BDH Chemicals Ltd, Poole, England) was added and the mixture centrifuged at $2000 \times \mathrm{g}$ for $8 \mathrm{~min}$. The upper layer $(2 \mathrm{~mL})$ was mixed with $5 \mathrm{~mL}$ of deionised water and $1 \mathrm{~mL}$ of $0.1 \%$ of ferric chloride, and the absorbance read at $700 \mathrm{~nm}$. Higher absorbance indicates higher reducing power (Oyaizu, 1986).

\section{Total Antioxidant content of honey}

The antioxidant content was determined by measuring Ascorbic acid Equivalent Antioxidant Capacity (AEAC) values using the method of Meda et al.(2005)
Briefly, honey samples were dissolved in methanol to a final concentration of $0.03 \mathrm{~g} / \mathrm{mL}$. A $0.75 \mathrm{~mL}$ aliquot of the methanolic honey solution was then mixed with $1.50 \mathrm{~mL}$ of $0.02 \mathrm{mg} / \mathrm{mL}$ DPPH solution prepared in methanol. The mixture was then incubated at room temperature for $15 \mathrm{~min}$, and the absorbance measured at $517 \mathrm{~nm}$. The blank was composed of $0.75 \mathrm{~mL}$ of a methanolic honey solution mixed with $1.5 \mathrm{~mL}$ of methanol. Ascorbic acid standard solutions (2, 4, 6, 8 and $10 \mu \mathrm{g} / \mathrm{mL}$ ) prepared in distilled water were used to form a calibration curve. Measurements were performed in triplicate, and the mean value was expressed as $\mathrm{mg}$ of ascorbic acid equivalent antioxidant content per $100 \mathrm{~g}$ of honey.

\section{Analysis of citrus fruit juice}

\section{Determination of total acidity and $\mathrm{pH}$}

Total acidity of the juices was determined by titration method according to Rekha et al.(2012). A $10 \%$ fruit juice was prepared and $10 \mathrm{~mL}$ titrated against standardized $0.1 \mathrm{~N} \mathrm{NaOH}$ (Sodium hydroxide) using Phenolphthalein as an indicator. The end-point was noted. Total acidity was calculated in terms of citric acid using formula:

Acidity $(\mathrm{g} / 100 \mathrm{~mL})=$ Normality of the juice $\mathrm{x}$ Equivalent weight of citric acid.

The $\mathrm{pH}$ of $10 \%$ juice was determined using $\mathrm{pH}$ meter (Mettler Toledo, USA)

\section{Estimation of Ascorbic acid content}

Ascorbic acid content in fruit juices was estimated by titration method. Into a 100 $\mathrm{mL}$ volumetric flask, $50 \mathrm{~mL}$ of un-diluted fruit juice and $25 \mathrm{~mL}$ of $20 \%$ metaphosphoric acid was added as a stabilizing agent and distilled water added up to the $100 \mathrm{~mL}$ mark. A $10 \mathrm{~mL}$ volume of the solution was pipetted into a small flask and titrated using standard indophenols solution until a faint pink color persisted for $15 \mathrm{~s}$. The $\mathrm{mg}$ of Ascorbic acid per $\mathrm{mL}$ of the sample was calculated as follows:

Vitamin $C$ content $(\mathbf{m g} / \mathbf{1 0 0 g})=(A-B) \times C \times 100 / 10 \times 1 / S \times 100$

Where: $\quad \mathbf{A}=$ volume of the indophenols solution used to titrate the sample $(\mathrm{mL})$ $\mathbf{B}=$ volume of then indophenols solution used for the blank $(\mathrm{mL})$

$\mathbf{C}=$ mass in $\mathrm{mg}$ Ascorbic acid equivalent to $1.0 \mathrm{~mL}$ of standard indophenols solution

$\mathbf{S}=$ volume of sample used

\section{Determination of Antioxidant Activity of the Fruit Juices}

\section{DPPH free radical scavenging assay}

This was determined following the method proposed by Ferreira $\boldsymbol{e t}$ al.(2007) as described in the analysis of the honey samples.

\section{Ferric reducing assay}

This was determined following the method proposed by Ferreira et al. (2007) as described in the analysis of the honey samples.

\section{Total antioxidant content of fruit juices}

The antioxidant content of the fruit juices was determined by measuring Ascorbic acid Equivalent Antioxidant Capacity(AEAC) values using the method of Meda et al.(2005). From the three citrus fruits evaluated, the fruit with the highest ascorbic acid content and hence antioxidant activity was selected for use in the preparation ofomega-3 fortified yoghurt. The recommended dietary intake (RDI) of ascorbic acid (60mg/day) was used to determine the volume of the juice to be added into the yoghurt, and taking care that the $\mathrm{pH}$ of the yoghurt does not to go below the recommended $\mathrm{pH}$ of 4.5 .

\section{Production of fortified yoghurt}

Production of functional fortified yoghurt was done by a method developed in our laboratory. Two types of stirred fortified yoghurt samples were prepared. The first yoghurt sample was fortified with Omega-3 fatty acids and honey (YFH). Honey $(95 \mathrm{~g})$ was incorporated into 1 litre of milk during the yoghurt mix formulation and the mixture homogenized to ensure a homogenous formulation. Skimmed milk powder containing Soy lecithin was added as a thickener and to solubilize the omega- 3 rich oil in the yoghurt. The second yoghurt sample was fortified with Omega-3 fatty acids and $33.3 \mathrm{~mL}$ of lemon juice per 1litre of milk (YFL). The third yoghurt sample was a control, which contained only the oil sample without an antioxidant (YF). A fourth control comprised of plain natural yoghurt (PY). 


\section{Analysis of yoghurt after production and during storage}

Determination of Quality parameters of the omega-3 fortified yoghurt was done by determining the PV, AV, Total oxidation (TOTOX) and FFA contents. $\mathrm{pH}$ and total acidity was determined at weekly intervals over one month storage period.

\section{Statistical Analysis}

The entire experiment was replicated three times and the means and standard deviations reported. The SPSS software (IBM SPSS statistic 19) was used to conduct analyses of variance (ANOVA) to determine the differences among treatment means in the various weeks and the post hoc Tukey's test was used. Correlation analyses were done using the SPSS software.

\section{RESULTS AND DISCUSSION}

Biochemical parameters of the honey samples
The Phenol content per $100 \mathrm{~g}$ of honey ranged from $58.56 \mathrm{mg}$ to $71.56 \mathrm{mg}$ GAE (Table 1). The commercial honey samples had higher phenolic content compared to the natural honey samples. The phenolic content of the samples is in agreement with phenolic content of honey reported in literature (Beretta et al., 2005; Gheldof et al., 2002). A general observation can be made that dark honeys (Amboseli and Green forest) were characterized by considerably higher phenolic content than the natural honey sample. This trend is similar to the relationship found in previous studies done on Burkina Faso and Italian honeys (Blasa et al. 2006; Meda et al., 2005). The natural honey sample had higher proline content of $2.41 \pm 0.24(\mathrm{mg} / \mathrm{g})$, whereas the Amboseli and Green forest honey had less proline content. The proline levels obtained in all the samples exceeded the minimum limit, an indication that the honey samples were not adulterated (Table 1).Carotenoid such as $\beta$-carotene and lycopene were higher in the processed honey samples than in the natural honey. The color intensity $\left(\mathrm{ABS}_{450}\right)$ of the Natural honey $(219 \pm 23.43 \mathrm{mAU})$ was lower than that of the processed honey samples with Amboseli honey having highest ABS. This suggested a lower antioxidant activity in the natural honey compared to processed honey.

Table1 Biochemical and physical parameters of the honey samples

\begin{tabular}{|c|c|c|c|c|c|}
\hline Sample & $\begin{array}{l}\text { Phenol content } \\
\quad(\mathrm{mg} / \mathbf{1 0 0 g})\end{array}$ & $\begin{array}{l}\text { Proline content } \\
\text { (mg/g) }\end{array}$ & $\begin{array}{c}\beta \text {-Carotene } \\
(\mathrm{mg} / \mathrm{kg})\end{array}$ & Lycopene(mg/kg) & $\begin{array}{c}\text { Color intensity } \\
(\mathbf{m A U})\end{array}$ \\
\hline Baringo (Natural) & $58.56 \pm 1.78$ & $2.41 \pm 0.24$ & $7.23 \pm 0.92$ & $5.31 \pm 0.52$ & $219 \pm 23.43$ \\
\hline Amboseli (Processed) & $67.25 \pm 0.89$ & $1.62 \pm 0.53$ & $8.31 \pm 1.02$ & $6.71 \pm 0.02$ & $406 \pm 12.34$ \\
\hline Green forest (Processed) & $71.56 \pm 2.34$ & $1.72 \pm 1.02$ & $8.92 \pm 0.32$ & $6.81 \pm 0.01$ & $394 \pm 11.68$ \\
\hline
\end{tabular}

Values presented are mean $\pm S D$ of three determinations

\section{Antioxidant activities of honey samples}

The antioxidant activity of honey varied from $65.7 \%$ to $86.2 \%$ in the DPPH reaction system. The results of the DPPH radical scavenging activity showed that the processed honey tended to be highly active in the reaction with DPPH, while
Natural honey had a lower radical scavenging activity. The Baringo sample had lower AEAC $(280 \pm 0.56)$ compared to the Amboseli $(305 \pm 1.23)$ and Green forest $(312 \pm 2.34) \mathrm{mg}$ of AEAC/kg of honey (Table 2). Green forest honey had higher reducing activity $(2.78 \pm 1.69)$ compared to Amboseli $(2.56 \pm 1.23)$ and Baringo (0.98 \pm 2.54$)$

Table 2 Antioxidant activity of honey samples

\begin{tabular}{lccc}
\hline Sample & DPPH Scavenging activity (\%) & $\begin{array}{c}\text { Ferric Reducing power Abs } \\
\text { at 700nm }\end{array}$ & $\begin{array}{c}\text { Antioxidant content (mg of AEAC/kg } \\
\text { of honey) }\end{array}$ \\
\hline Baringo (Natural) & $65.86 \pm 2.94$ & $0.98 \pm 2.54$ & $280 \pm 0.56$ \\
Amboseli (Processed) & $84.47 \pm 2.58$ & $2.56 \pm 1.23$ & $305 \pm 1.23$ \\
Green forest (Processed) & $86.16 \pm 1.43$ & $2.78 \pm 1.69$ & $312 \pm 2.34$ \\
\hline
\end{tabular}

Values shown are means $\pm S D$ of three replicate experiments

\section{Correlations amongst biochemical parameters and antioxidant potentials}

Several strong correlations were established amongst different biochemical and antioxidant parameters. A strong correlation was found between the color intensity of honey samples and antioxidant parameters (DPPH and AEAC) (Table 3 ). Strong correlations between the $\beta$-carotene, lycopene and AEAC suggest that these components contribute to anti-oxidative capacity of honey (Ferreira, et al. 2007). These findings suggest that honey color pigments such as $\beta$-carotene and lycopene may have a role in the observed antioxidant activities of honey samples. Similar to our findings, a strong correlation between the antioxidant capacity and $\mathrm{ABS}_{450}$ was reported by Bertoncelj et al. (2007) and Beretta et al.(2005) indicating that honey color intensity may be treated as a good initial indicator of its antioxidant capacity. A strong positive correlation was established between the antioxidant activity and total phenolic content $(\mathrm{PC})\left(\mathrm{R}^{2}=0.967\right.$ for $\mathrm{PC} / \mathrm{DPPH} \bullet$ $\mathrm{R}^{2}=0.976$ for $\mathrm{PC} /$ Ferric reducing assay, $\mathrm{R}^{2}=0.993$ for PC/AEAC. This means that phenolic compounds are one of the main components responsible for the antioxidant activity of honeys. This correlation was in agreement with the findings of other authors such as the high correlation between radical scavenging activity and the total phenolic content at a level of $\mathrm{p}=0.5$, (Meda et al., 2005). Overall, the strong positive correlations suggest that the honey samples had a strong antioxidant potential that could be utilized to prevent fish oil oxidation in the omega-3 fortified yoghurt.

Table 3 Correlation matrix showing the interrelation among biochemical parameters and antioxidant activity of honey

\begin{tabular}{|c|c|c|c|c|c|c|}
\hline & Proline & Bcarotene & Lycopene & $\mathbf{A B S}_{450}$ & DPPH & AEAC \\
\hline Proline & 1 & -0.887 & -0.985 & $-0.998 *$ & -0.982 & -0.947 \\
\hline$\beta$-carotene & -0.887 & 1 & 0.954 & 0.912 & 0.958 & 0.988 \\
\hline Lycopene & -0.985 & 0.954 & 1 & 0.993 & $1.000 * *$ & 0.989 \\
\hline $\mathrm{ABS}_{450}$ & $-0.998 *$ & 0.912 & 0.993 & 1 & 0.991 & 0.965 \\
\hline DPPH & -0.982 & 0.958 & $1.000^{* * *}$ & 0.991 & 1 & 0.991 \\
\hline
\end{tabular}

*Correlation is significant at 0.05 levels (2-tailed)

**Correlation is significant at 0.01 levels (2-tailed)

\section{Total acidity, pH and ascorbic acid content of Citrus fruits}

Citrus fruits contain high levels of citric and ascorbic acid. In this study, ripe fruits were used since unripe ones contain lower $\mathrm{pH}$ than ripe fruits (Rekha et al. 2012) which would further reduce the $\mathrm{pH}$ of the fortified yoghurt below unacceptable levels. The $\mathrm{pH}$ was lowest in lemon juice $(2.9 \pm 0.02)$ because lemon juice contains higher amounts of ascorbic acid in addition to citric acid Orange and tangerine juice had a $\mathrm{pH}$ of $3.8 \pm 0.01$ and $4.1 \pm 0.01$, respectively.
The total acidity was higher in lemon juice followed by orange juice and then Tangerine. $\mathrm{pH}$ and total acidity are important in determining the level of acidity of the juices which may affect the acidity of the yoghurt once added. The ascorbic acid content in the fruit juices ranged from $55.25 \pm 0.34$ to $62.82 \pm$ $0.48 \mathrm{mg} / 100 \mathrm{~mL}$. The highest ascorbic acid content was observed in lemon juice followed by orange and tangerine (Table 4). 
Table 4 Total acidity, pH, Ascorbic acid content, DPPH free radical scavenging activity, Ferric reducing activity and total antioxidant content (AEAC) of citrus fruit juices

\begin{tabular}{lccccc}
\hline Citrus fruit & pH & $\begin{array}{c}\text { Total acidity } \\
\text { (Citric acid } \\
\text { g/100 ML) }\end{array}$ & $\begin{array}{c}\text { Ascorbic } \\
\text { acid(mg/100 mL) }\end{array}$ & DPPH (\%) & $\begin{array}{c}\text { Ferric reducing } \\
\text { activity (Abs } \\
\mathbf{7 0 0 n m})\end{array}$ \\
\hline Orange juice & $3.8 \pm 0.01$ & $0.8 \pm 0.01$ & $55.25 \pm 0.34$ & $62.06 \pm 2.56$ & $0.98 \pm 1.54$ \\
Lemon juice & $2.9 \pm 0.02$ & $3.7 \pm 0.01$ & $62.82 \pm 0.48$ & $71.29 \pm 3.52$ & $1.34 \pm 0.65$ \\
Tangerine juice & $4.1 \pm 0.01$ & $0.6 \pm 0.02$ & $57.34 \pm 1.54$ & $59.02 \pm 1.67$ & $0.78 \pm 1.92$ \\
\hline
\end{tabular}

Values shown are means $\pm S D$ of three replicate experiments

\section{Radical scavenging and Ferric reducing Power}

Radical scavenging activities of citrus juices investigated by DPPH radical scavenging assay showed that lemon juice had the strongest scavenging activity $(71.29 \pm 3.52 \%)$ compared to orange $(55.06 \pm 2.56)$ and tangerine $(51.02 \pm 1.67)$ (Table 4). Antioxidant activity was found to be higher in lemon juice, which also had the highest level of ascorbic acid. This is in accordance with results obtained in previous studies by (Gardner et al., 2000).Gardner et al, (2000) also showed that vitamin $\mathrm{C}$ is the main antioxidant in most of the citrus fruits. Ferric reducing assay showed that lemon juice had the strongest activity. This was in agreement with a study done by Ali et al. (2011), which showed that citrus fruits had a high DPPH radical scavenging, and ferric reducing antioxidant potential. Although the antioxidant capacity evaluated by the DPPH method was higher than that evaluated by the Ferric reducing assay method, the correlations were good for both methods. This indicated that ascorbic acid contributed to the antioxidant activity of the citrus fruits. Other than the antioxidant potential of citrus fruits, a recent study by the World Health Organization showed convincing evidence of positive effects obtained from dietary intake of citrus fruits on cardiovascular disease (WHO, 2003). They have also been shown to possess anti-inflammatory, antioxidant, antitumor and antifungal activities (Ghafar et al., 2010).

Correlation matrix showing the relationship between Ascorbic acid content and Antioxidant activity of Citrus fruits

All the parameters evaluated to show the antioxidant potential of citrus fruit juices showed strong positive correlation (table 5). A strong positive correlation was evident between ascorbic acid content and total antioxidant activity $\left(\mathrm{R}^{2}=\right.$ 0.997). Citrus fruits are a good source of vitamin $C$ and they also possess good antioxidant activity (Berenguer $\boldsymbol{e t}$ al., 2004). Lemon juice was the best in terms of ascorbic acid content and hence highest antioxidant capacity, it is available every season and very economical compared to the other studied fruits Therefore, lemon juice was chosen for the fortification process of the yoghurt.

Table 5 Correlation matrix showing the relationship among Ascorbic acid content and antioxidant activity of Citrus fruits

\begin{tabular}{lcccc}
\hline & $\begin{array}{c}\text { Ascorbic } \\
\text { acid }\end{array}$ & DPPH & $\begin{array}{c}\text { Ferric } \\
\text { reducing } \\
\text { activity }\end{array}$ & AEAC \\
\hline Ascorbic acid & 1 & 0.872 & 0.808 & 0.830 \\
DPPH & 0.872 & 1 & 0.993 & 0.997 \\
Ferric reducing activity & 0.808 & 0.993 & 1 & $0.999 *$ \\
AEAC & 0.830 & 0.997 & $0.999 *$ & 1 \\
\hline
\end{tabular}

*Correlation is significant at 0.05 levels (2-tailed)

Changes in Peroxide, Anisidine, Totox and FFA of the fish oil fortified yoghurt over four-week storage period

The PV, AV, and TOTOX values of the omega-3 fortified yoghurt increased slightly over time in all the samples with honey (YFH) having the least values followed by lemon juice and the highest values seen in the sample without antioxidant (YF). The FFA value in the lemon juice fortified sample (YFL) was higher than the sample with no antioxidant up to the third week. This is because FFA estimation is a titration method and thus the increased acidity in this sample gave the high FFA content. In the fourth week, a gradual increase in FFA in all the samples was observed overtime with the control (YF) having the highest FFA values (figure 1). When comparing samples with added antioxidants with those without anti-oxidants, it was found that the latter samples had lower values of these quality parameters. The antioxidants therefore, helped to reduce lipid peroxidation of the fish oils. Honey was a better antioxidant compared to lemon juice. This is because honey has several compounds that play a critical role in antioxidant activity such as phenols, flavonoids, carotenoids(Ferreira $\boldsymbol{e t}$ al. 2007) compared to lemon juice which has only ascorbic and citric acid as the major compounds enhancing its antioxidant activities. From this study, honey and vitamin $\mathrm{C}$ can be used as natural antioxidants in yoghurt fortified with omega-3 rich fish oil thereby extending its shelf life.
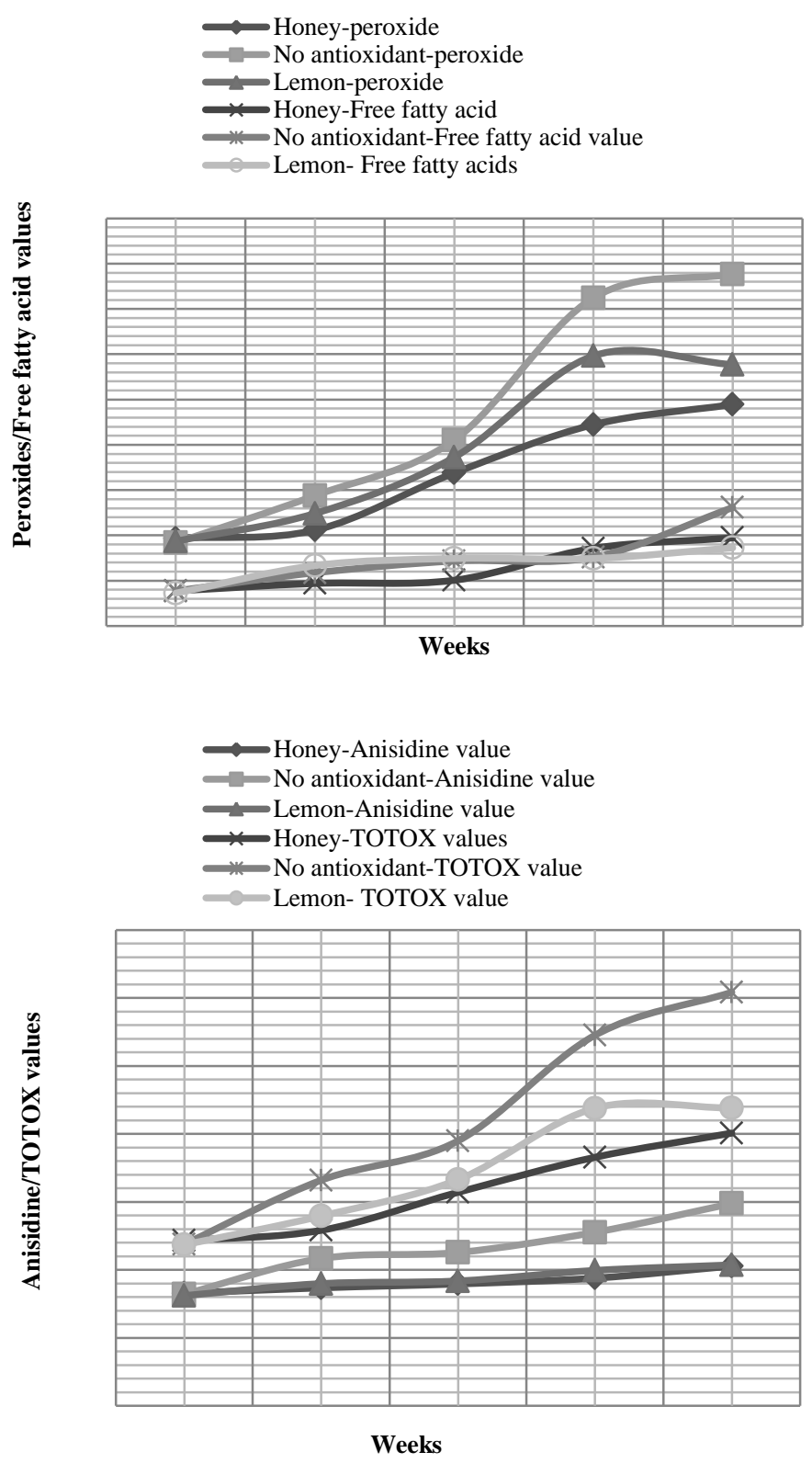

Figure 1 Changes in quality parameters of the fortified yoghurt over four-week storage period

\section{Changes in pH, Total acidity over four week's storage period}

Overall, the $\mathrm{pH}$ values in all the samples decreased slightly over time (figure 2). The total acidity increased slightly in all the samples with the highest $\%$ in the lemon juice fortified yoghurt (YFL). The lemon juice fortified yoghurt sample had the highest vitamin $\mathrm{C}$ content compared to all other samples. Generally, the $\mathrm{pH}$ values in all the samples decreased slightly over time. The sample with lemon juice as antioxidant had very low $\mathrm{pH}$ due to the presence of citric acid in addition to Ascorbic acid in the juice. The other three samples (PY, YF, and YFH) had close $\mathrm{pH}$ values with the plain natural yoghurt having the highest $\mathrm{pH}$ values. The total acidity increased slightly in all the samples with the highest percentage in the lemon juice fortified yoghurt. Starter cultures usually transform lactose in milk into lactic acid which is responsible for the initial acidification which coagulates the milk at $\mathrm{pH} 4.5$ and also the post acidification during storage. 

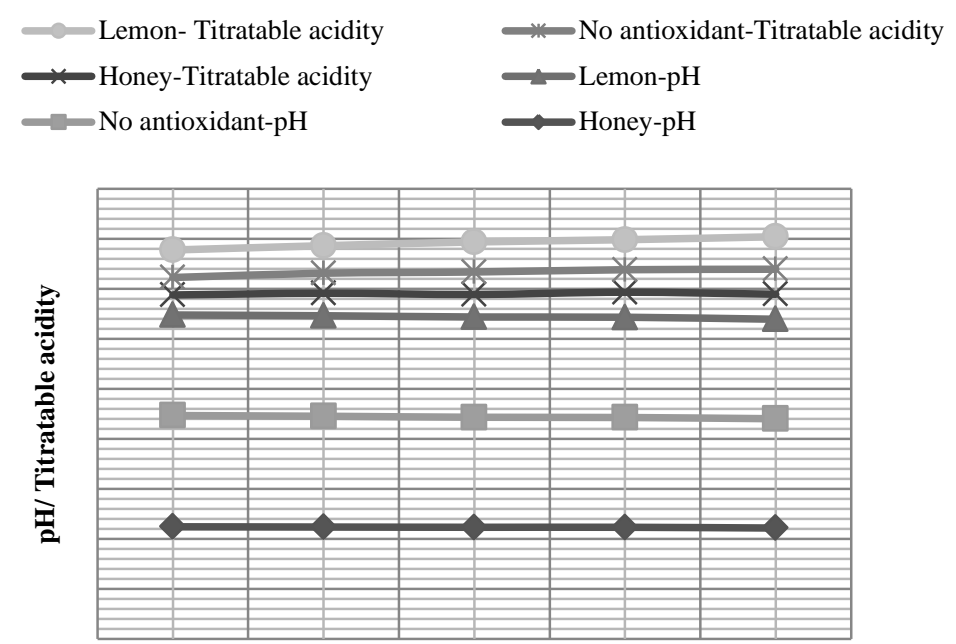

Weeks

Figure 2 Changes in $\mathrm{pH}$ and titratable acidity of the different yoghurt samples over four weeks storage period

\section{CONCLUSION}

The greatest challenge in the addition of omega- 3 rich oils to yoghurt as a source of n-3 FA is their extreme sensitivity to oxidation that leads to the development of off-flavors. The goal is to add sufficient levels of oil that can provide a significant contribution of omega-3 fatty acids into the daily diet while minimizing oxidation. This therefore calls for the need to add natural antioxidants and flavors to reduce oxidation and fishy flavor. Several natural antioxidants can be exploited to help delay oxidation of the fish oils in the fortified yoghurt. In our study honey and lemon juice were shown to have good anti-oxidative properties and this helped delay oxidation of the fish oils in the fortified yoghurt.

\section{REFERENCES}

ALI, M., NAYAN, V., CHANU, K., RALTE, L., \& DEVI, L.(2011).Antioxidan activity of fruits available in Aizawi market of Mizoram, India.WorldJ Agricultural Sci7(3): 327-332.

AMEGOVU, A. K., OGWOK, P., OWOR, S., YIGA, P., MUSALIMA, J. H., \& MANDHA, J. (2014). Sensory Acceptability of Sorghum Peanut Blend ( SPB ) and Corn Soy Blend Plus ( CSB + ) By Young Children With Moderate Acute Malnutrition in Karamoja, Uganda, 3(2). http://dx.doi.org/10.5539/jfr.v3n2p17 BERENGUER, A., QUIRO, R., AGUDO, A., \& GONZA, C. A. (2004). Dietary sources of vitamin C, vitamin E and specific carotenoids in Spain. British Journal of Nutrition 1005-1011. http://dx.doi.org/10.1079/bjn20041130

BERETTA G., GRANATA P., FERRERO M., ORIOLI M., \& FACINO R.M. (2005).Standardization of antioxidant properties of honey by a combination of spectrophotometric/fluorometricassays and chemometrics.Anal. Chim. Acta, 533 , 180-191.

http://dx.doi.org/10.1016/j.aca.2004.11.010

BERTONCEJL J., DOBERSEK U., JAMNIK M., \& GOLOB T. (2007). Evaluation of the phenolic content, antioxidant activity and color of Slove- nian honey. Food Chemistry 105, 822-828. http://dx.doi.org/10.1016/j.foodchem.2007.01.060 BLASA,M., CANDIRACCI, M., ACCORSI, A., PIACENTINI, M.,ALBERTINI, M., \& PIATTI, E. (2006). Millefiori honey is packed full of antioxidants. Raw Food Chemistry 97: 217-222.

http://dx.doi.org/10.1016/j.foodchem.2005.03.039

BLIGH, E., \& DYER, W., (1959). A rapid method for total lipid extraction and purification. Can. J. Biochem Physiology. 37:911-917

FERREIRA, I. C. F. R., AIRES, E., BARREIRA, J. C. M., \& ESTEVINHO, L. M. (2007).Antioxidant activity of Portuguese honey samples: Different contributions of the entire honey and phenolic extract. Food Chemistry, 114(4), 1438-1443. http://dx.doi.org/10.1016/j.foodchem.2008.11.028

GARDNER, P., WHITE, T., MCPHAIL, D.\& DUTHIE,G. (2000).The relative contributions of vitamin $\mathrm{C}$, carotenoids and phenolics to the antioxidant potential of fruit juices - dietary flavonoids and phyto-estrogens. Food chemistry. 68, 471474.

http://dx.doi.org/10.1016/s0308-8146 (99)00225-3

GHAFAR, M., PRASAD, K., WENG, K., \& ISMAIL A, (2010).Flavonoid, hasparidine, total phenolic content and antioxidant activities from Citrus species. African Journal of Biotechnology., 2010, 9(3), 326-330.
GHELDOF, N., WANG, X., \& ENGESETH, X. (2002).Identification and quantification of antioxidant components of honeys from Chemistry various floral sources. Journal of Agricultural and Food Chemistry 50: 5870-5877. http://dx.doi.org/10.1021/jf0256135

HUBER, G., RUPASINGHE, H., \& SHAHIDI, F. (2009). Inhibition of oxidation of omega-3 polyunsaturated fatty acids and fish oil by quercetin glycosides. Food Chemistry, 117(2), 290-295.

http://dx.doi.org/10.1016/j.foodchem.2009.04.007

IVAREZ, S.J., TULIPANI, S., ROMANDINI, S., BERTOLI, E.,\& BATTINO, M. (2010).Contribution of honey in nutrition and human health: a review. Mediterranean J NutrMetab2010,3:15-23

http://dx.doi.org/10.1007/s12349-009-0051-6

JELLINEK, G. (1971).masking undesirable flavors in fish oils' experiment imasking tests. Fish. Bull., U. S.69(I), 215-222.

LEE, S. K. \& KADER, A. A. (2000). Postharvest Biology Technology, 2000, 20(3), 207-220.

MEDA, A., EULOGE, C., ROMITO, M., MILlOGO, J., \& GERMAINE, O. (2005). Determination of the total phenolic , flavonoid and proline contents in Burkina Fasan honey, as well as their radical scavenging activity. Food Chemistry 91, 571-577. http://dx.doi.org/10.1016/j.foodchem.2004.10.006

METCALF, R. G., JAMES, M. J., MANTZIORIS, E., \& CLELAND, L. G. (2003). A practical approach to increasing intakes of n-3 polyunsaturated fatty acids: use of novel foods enriched with n-3 fats. European Journal of Clinical Nutrition, 57(12), 1605-12. http://dx.doi.org/10.1038/sj.ejcn.1601731

MOHAMMED, M., IBRAHIM, M., SITI, A. \& SIEW H. (2013). Physiochemical and antioxidant properties of Malaysian honeys produced by Apis Cerena, Apis dorsata and Apis mellifera. BMC Complementary and Alternative Medicine 13:43 OYAIZU, M. (1986). Studies on rpoducts of browning reactions : antioxidative activities ofproducts of browning reaction prepared from glucosamine. Japanese Journal of Nutrition, 44:307-315.

http://dx.doi.org/10.5264/eiyogakuzashi.44.307

REKHA, C., POORNIMA, G., MANASA, M., ABHIPSA, V., \& DEVI, J. P. (2012). Ascorbic Acid, Total Phenol Content and Antioxidant Activity of Fresh Juices of Four Ripe and Unripe Citrus Fruits. Chem Sci Trans 1(2), 303310 doi: $10.7598 /$ cst2012.182

SARKAR, N., SRIVASTAVA, P. K. \& DUBEY, V. K. (2009).Curr Nutri Food Sci., 5, 53-55.

http://dx.doi.org/10.7598/cst2012.182

SEEMA, P \& SIMON, C. (2013). Manuka honey: an emerging natural food with medicinal use Review Nat. Prod. Bioprospect., 3, 121-128 http://dx.doi.org/10.1007/s13659-013-0018-7

SINGLETON, V.,ORTHOFER,R. \& LAMUELA,R. (1999).Analysis of total phenols and other oxidation substrates and antioxidants by means of folinciocalteu reagent. Methods Enzymol.299:152-178.

http://dx.doi.org/10.1016/s0076-6879(99)99017-1

STIP, T., \& BELŠ, A. (2009). Antioxidant properties and phenolic content of different floral origin honeys. Journal of Apiproduct and Apimedical Sciencel (2):43-50.

http://dx.doi.org/10.3896/ibra.4.01.2.04

WORLD HEALTH ORGANISATION. (2003). Diet, Nutrition and the Prevention of Chronic Disease. Report of a joint WHO/FAO Expert Consultation, Geneva. http://www.who.int/hpr/NPH/docs/who_fao_expert_report.pdf 